\title{
Ritual Formalism and the Intangible Body of the Japanese Koryū Budō Culture
}

\author{
LEO RAFOLT \\ Faculty of Humanities and Social Sciences, Zagreb
}

\begin{abstract}
The paper presents an analysis of the interrelation between the traditional Japanese martial arts culture (koryū budō) and its modern correspondents (gendai budō). The analysis is based on the idea of inscribing koryū budō on UNESCO's list of intangible cultural heritage, as Japan's oldest martial cultural asset. Initial proposals to do so were put forward in the last ten years by some Japanese martial arts organizations, e.g. Nippon Budokan, especially by its koryū legacy division. The paper interprets the ritual-like and pattern-like formalism of the Japanese modern and traditional budō legacy, especially in the context of "Japanese nationalist history" after the Meiji Restoration. Emphasis is therefore put on the structures of movements that pre-exist in the ritual practices of the classical budō culture and are still present in modern martial arts systems, because of their hereditary and pre-formalized performativity.
\end{abstract}

Key words: koryū budō, gendai budō, ritual, kata, Japanese martial arts

The Japanese were the most alien enemy the United States had ever fought in an all-out struggle. In no other war with a major foe had it been necessary to take into account such exceedingly different habits of acting and thinking [...]. Conventions of war which Western nations had come to accept as facts of human nature obviously did not exist for the Japanese. It made the war in the Pacific more than a series of landings on island beaches, more than an unsurpassed problem of logistics. It made it a major problem in the nature of the enemy. We had to understand their behavior in order to cope with it. (Benedict 1954 [1946]: 1)

\section{INTRODUCTION: MISCONCEPTIONS}

Far-Eastern martial arts and combat disciplines (especially Japanese, Korean, Filipino, Vietnamese or Chinese) are nowadays widely known in the Western societies, although they have stopped gaining popularity in the last 
couple of decades. ${ }^{1}$ Even the Japanese society has lost its interest in both modern and ancient martial ways (bujutsu, budō): nowadays they may seem as too complex, they have an aura of esotericism, mysticism, which remains impenetrable in the rationalist milieu of the contemporary Japan, they have not managed to establish a clear stance towards their nationalist and militarist heritage, etc. Many martial arts were forbidden during the control period imposed by the Americans after World War II. After the controlling American forces left the Japanese soil in 1952, some modern martial arts were included in the educational systems or physical activity curriculums in Japan, as well as in a number of other, Western countries (Australia, America), because of pedagogical values they promote, the sportive-competitive nature they contextualize, or because of the rich cultural background and the important role they played in preserving national heritage (Sugie 2009; Kanno 2009). Some of the martial arts transformed their legacy into westernized sports and leisure activities. About half a century ago some became members of the Olympic family of sports and of different national or international organizations, like jūdō, kendō, karatedō, subsequently kyūdō, sumō and aikidō. In 1977, some thirty years after the occupying allied United States forces imposed a ban on practicing budō, nine of the most dominant Japanese national martial arts federations (jūdō, kendō, kyūdō, sumō, karatedō, aikidō, shōrinji kempō, naginata and jūkendō) decided to establish the Japanese Budō Association (Nippon Budō Kyogikai), with the main purpose of preserving Japanese budō as a significant and even a constitutive element of the Japan's cultural heritage, thus adhering to the pre-war efforts of the kind undertaken by organizations such as the Great Japanese Association of Martial Virtue (Dai Nippon Butokukai). Given that during the war - from the European and Anglo-American standpoint - such efforts have been strongly associated with the propulsive militarism and the newly-born Japanese nationalist ideologies, it took almost half a century to decontaminate traditional Japanese budo from this imposed semantics. During the opening ceremony of the Japanese Budō Association in 1964 the award-winning novelist and critic Inoue Yasushi traced the legacy of the budo culture back to its humanistic roots, giving an inaugural speech about the essence of traditional budo from the perspective of the literary legacy. During the 1960s many scholars, but mainly anthropologists and ethnologists, recognized a need for a scholarly approach to all aspects of classical Japanese martial arts culture. Many leading universities took this opportunity to establish new budō culture faculties, academic circles, or to promote journals and congress meetings all around

\footnotetext{
${ }^{1}$ Japanese terminology was romanized according to the modified Hepburn system, where the macron was mainly used for long vowels, rather than doubling the vowels or blending the final vowel with the proceeding one (e.g. sumō is used instead of sumou). Cursive is used occasionally, in the brackets or for emphasis, names and periods were left intact, without macrons.
} 
the globe. Today many top universities in Japan specialize in koryū budō culture as a part of the broadly perceived national cultural history (Motomura 2009; Oboki 2009). ${ }^{2}$

In this paper I will focus on some elements of the Japanese koryū budō tradition by scrutinizing them against the background of the UNESCO's definition of intangible cultural heritage. For an element to be proclaimed intangible cultural heritage it should incorporate three elements: a traditional, contemporary and a living component (UNESCO, Article 1-3). Thus, in this paper the Japanese koryū styles will be presented as a martial culture system with its strong traditional or essential historic (kobudō) background, as well as its living/contemporary correspondent in different modern or modernized (gendai) martial arts systems. Secondly, the intangible cultural heritage should be inclusive and passed from one generation to another, thus evolving in response to the social environment, by providing a sense of identity and continuity, a link from the past to the present and into the future. The hereditary principle of koryū budo (iemoto) will thus be examined in this paper as one of its central components. Thirdly, intangible assets should be representative in the context that communities provide for them and they should depend upon those whose knowledge of traditions, skills, techniques and customs is passed on to the rest of the community, or from generation to generation, or to other communities. This representative status of koryū budō will be emphasized in the context of its performativity, in the concluding segments of the paper. Finally, intangible cultural heritage can be recognized as such by the communities, groups or individuals that create, maintain and transmit it. A short history of the institutional background of koryū budō culture will thus be presented. In this context, the following emerges as central to this paper: (1) koryū (or kobujutsu) styles should be perceived as Japan's intangible cultural heritage because they have all the components of UNESCO's definition of intangible cultural heritage assets; (2) one of the main components examined in this paper is the koryū budō's ritual-performative structure; (3) this part of Japan's oldest martial traditions will therefore be examined from the standpoint of its performativity or structured-movement-strategies in this performativity's background; (4) the changeable circumstances in which martial culture in modern Japan has evolved will be discussed against the institutional background of koryū

\footnotetext{
${ }^{2}$ Connections between the literary culture, arts and budō culture have been inherited from the past. Samurai, feudal noble warriors, were to be perceived as a well-educated and highly sophisticated military class, usually oriented towards bunbu ryōdō, a social concept and a political philosophy emphasized by the shogunate during the Tokugawa period (1603-1867), that can be summarized as taking the path of cultural learning as well as martial arts. Consequentially it had evolved into two directions: the first one leading towards the idea of cultification of the samurai class (in a way, it could be interpreted as samurai humanism) and the second one leading to the ideology of pacifism. The role of ideology in the Japanese nation-state is explored by Culiberg (2007: 123-152).
} 
budō (or different institutions dedicated in preserving and re-examining its legacy); (5) the evolution of modern budō system, in all of its diversity, will be presented as a logical consequence of demilitarization of koryū styles; (6) finally, koryū budō legacy will thus be put in the militarist context of the Meiji era regime, which will subsequently explain why most Japanese institutions have had some inner inhibition in promoting and codifying koryū budō as national cultural heritage. In general, it should be stated that other cultures did not face the same problem in advancing their legacy. The Korean martial art of taekkyon recently (2011) became part of UNESCO's list of intangible cultural heritage, although there were strong disagreements about its actual inheritance and historical background. Some authors claim that taekkyon belongs to the circle of the so-called invented traditions, as it was more like a playful ritual for the lower classes then an actual martial and combat tradition. Inventing procedures accumulated around taekkyon phenomena include the following: forging its historical legacy or manipulating the context surrounding this game-ritual-play, and connecting it to the modern Korean martial art of taekwondo, as its supposed predecessor (Cho et al. 2012). Japanese cultural policy managed to include a variety of rituals, festivals, crafts, dance or theatre facets etc. on UNESCO's list, but martial arts traditions were just recently considered for inclusion, even though there was strong pressure from Okinawan (or Ryukyu) prefecture cultural heritage representatives to inscribe classical Okinawa (ryūkyū kobudō) styles on the list, where karatedō is just one of the most recognizable traditions (arts). ${ }^{3}$ UNESCO's Article 2 emphasizes the festive and ritual nature of intangible cultural heritage assets, including sport-like or athlete-like entertainment. The culture of budō is indubitably one of Japan's most significant contributions to the world's athletic as well as performative-aesthetic or festive intangible (cultural) heritage, while some consider budo as one of the most prominent Japanese cultural exports. There could be several reasons underlying the almost habitual bringing of the budo legacy into some sort of relation with Japan, some of them being sociocultural (in the case of Nikkeijin, Japanese descendants, or newly settled immigrants who attempted

\footnotetext{
${ }^{3}$ Many martial arts ethnographers and historians recently published about the problems of the Korean martial arts codification and standardization procedures, especially in the case of kumdo, hapkido and taekkyon as invented traditions. Alexander Bennett states that "this interesting phenomenon of the gradual Koreanization of budo overseas is perceived by the Koreans as the internationalization of their own Korean martial arts heritage. The Koreans are aggressive in their dissemination, sometimes nationalistic, and often very commercial in their approach, providing attractive packages for their students and instructors alike" (2005a: 327). Furthermore, the commercial-oriented-colonialism of this sort is not limited to Korea and is observable in some other martial arts cultures as well, but the impact of the above-mentioned Koreanization is so evident that it encouraged a variety of perspectives in the dispute. Koreans even established the World Martial Arts Union (WoMAU), an NGO association with the mission of promoting martial arts cultural diversity worldwide. In 2010 WoMAU received official patronage from UNESCO.
} 
to keep in contact with their heritage, e.g. Brazilian and Hawaiian), and/ or economical (marketing or advertising strategies in the West are often based on superficial interpretations of the so-called samurai bushid $\bar{o}^{4}$ code precepts), even military-historical (there are a number of Japanese martial arts schools in the West whose founders claim that they were introduced to Japanese budō during their military service in Japan after World War II). Indeed, for many Japanese during the 1930s, before the war, to learn budo usually meant to learn how to be a patriot and a militarist, in accordance with the regime's propaganda. At that point precisely, old-school budō (as well as all its more modern equivalents) managed to re-enter the Japanese primary and secondary education system and to enlist a lot of new members. On the other hand, for many American soldiers, soon after Japan was defeated, to study Japanese martial arts culture, in Japan, although in highly controlled circumstances, meant to acquire a certain piece of living Japanese heritage (Benedict 1954; Bennett 2005).

\section{COMPLEXITIES OF BUDŌ CULTURE}

According to the central Japanese budō research institution, Nippon Budōkan, martial arts that should be considered as a continuing legacy of the Japanese military culture and warfare are the following: jūdō, karatedō, kendō, kyūdō, sumō, aikidō, shōrinji kempō, naginata and jūkendō. Jūdō and karatedō are probably the most well known among the above-mentioned ones, especially in the West, although the popularity of arts like kendō, kyūdō, aikidō and sumō is definitely decreasing among Western practitioners. Although Jigoro Kano, the founding figure of jūdō, made a lot of efforts during the 1930s to include this art in the international spheres of physical education, leisure and sports, unfortunately, even in the 1950s and early 1960s, it still remained a central component of Japan's patriotic/militaristic education. Jigoro Kano had a unique idea of cultivating traditional, ancient Japanese martial arts, believing that this would separate them from the over-imposed nationalist

${ }^{4}$ Bushidō is usually defined as a way of the warrior or the warrior's code of ethics. It should be interpreted as the utmost restrictive view of warriorship, developed during the seventeenth century and influenced by many ethical-philosophical treatises, Hagakure being the most famous one. Before this code was established, petrified, there was a different concept of warriorship present, most probably borrowed from the ancient Chinese military strategies, called kyūba no michi, a way of the ridding arrow (Hall 2012: 297-298). The most influential modern interpretation of bushidō values was given by Inazo Nitobe, one of the most famous diplomats of the Meiji and Taisho period: when he was asked to describe the social, political and moral order underpinning the modern Japanese society, he wrote a book Bushidō: the Soul of Japan (1905), thus emphasizing the following features of "the code": strong ethics, relying upon justice, bravery, suffering, sincerity and politeness, specific system of honor, loyalty and educative values, institutions of suicide and revenge, etc. (Nitobe 2012). 
and militarist genealogy. On one occasion he summarized his way of making dialogue with the ancient styles of budō:

Whenever I met instructors from different schools, I was able to learn a great deal through discussions and exchanging texts (densho) and oral teachings (kuden). When I set out on my research, I was fortunate that some teachers of the traditional schools were still alive. These eminent masters greatly desired to pass on their knowledge but there were few students interested in learning. Learning this dire state of affairs, and without the need for me to make a formal request, a number of them came to me of their own volition to talk about their arts. "I hear you are very passionate about jūjutsu. I have studied jüjutsu for many years and accrued much knowledge. It would be most unfortunate to die without passing on these skills, and so I would like to share them with you." They taught me many things. In the past, these masters would not have been so quick to disclose their knowledge even to their own apprentices, but they conveyed it without reserve to me. In the bookshops and antique stores there were scores of (once secret) antique texts and scrolls outlining the teachings and techniques of classical schools (ryūha). I purchased all I could find, and was able to study the workings of many schools without needing to become a direct student. (cf. Bennett et al. 2009: 3)

This almost ethnographic testimony emphasizes the importance of traditional, ancient (koryū), classical, antique, as Kano calls it, styles (ryū) in transmitting knowledge about the technical legacy of budō. By the beginning of World War II Jigoro Kano, with a remarkable concept of jūdō, already succeeded in softening his art's militarist legacy: soon after the end of World War I, during the 1920s, he started putting more emphasis on the ethical precepts of jūdō, by creating the essential ideals of jūdō and presenting them in the form of theses to the Kōdōkan Cultural Council (Kōdōkan Bunkakai). These were socio-ecological theses about the maximally efficient use of one's energy (seiryoku-zenyo) and the pacifist idea about mutual prosperity for the self and others (jita-kyoei). It was about the same time that Morihei Ueshiba, the founder of aikidō and, like Kano, one of the leading reformists of the classical budō regime in Japan, started his own "codification" of the art, surprisingly using the similar principles as Jigoro Kano. Precepts employed by Kano and Ueshiba can be described as a transformation from "art" in its pragmatic and technical aspect (jutsu) to "art" in a much broader sense of "path" and even "philosophy" (dō). In an anthropological perspective this transformation is actually a way of transforming a classical, even ritualized legacy, based on the militarist ideals of combat virtues (bushidō), techni-

\footnotetext{
${ }^{5}$ Jigoro Kano wrote extensively about these issues of transforming jutsu to dō, mostly from the perspectives of the martial arts traditions and modern non-military martial systems, but also from the ethical standpoint (Kano 2006).
} 
cal effectiveness and warfare use, into the aesthetic, kinaesthetic, folklore dance-like, performance-like movement pedagogies, similar to any other conventional structures of movements, like those traceable in folk-dancing, folklore theatre performances, etc. All of the martial arts on UNESCO's list (taekkyon, Shaolin kungfu and, to some extent, Beijing Opera) are actually described as dance-like and/or performance-like (rhythmic) movement pedagogies. Precisely because of the importance of this change in the history of Japanese budō, from militarist use to pure kinaesthetics (transformation of jutsu to $d \bar{o}$ ), the rather complex distinction between martial arts traditionalists (koryū bujutsu) and modernists (gendai budō) should be re-examined.

Before I continue analyzing the even more complex relation between the two faces of Japanese martial arts history, the problematic relationship between jutsu and dō should be examined from a broader perspective. On a superficial level the situation is quite simple because, historically speaking, these traditions are intertwined. For example, merely a decade after the traditional koryū jutsu systems were totally suppressed in Japan, the All Japanese Jūdō Federation was established. Being a part of the All Japanese Sports Association since 1951, it also became affiliated with the Japanese Olympic Committee. Similar histories can be traced for kendō, kyūdō and sumō. After these were forbidden by the occupying forces, they were soon re-recognized by some of the international bodies, including the General Association of International Sports Federations (GAISF) and the International Olympic Committee (IOC), etc. Even before the 1920s some of the martial arts were promoted among many Western (competitive) disciplines. For example, kyūdō was presented in the London Olympics in 1908 by just a couple of Japanese practitioners who were, surprisingly, competing in Western-style archery. Nevertheless, all the above-mentioned styles of Japanese martial arts, nowadays very familiar, are not very old in tradition. In other words, they were also reformed as martial arts or combat strategies, some of them having not very clear historical roots and movement pedagogy. Usually they are referred to as $d \overline{0}$, according to the suffix in their name. But the procedure to become a $d \overline{0}$, from jutsu, was not so simple, at least according to the claims of modern martial arts scholars. Some of the Japanese budo anthropologists state that this difference (jutsu-dō) should be interpreted as a transfer from the ideological way of perceiving martial arts culture to a purely aesthetic one. However, it seems that such an interpretation is oversimplified. In order to explain the difference between koryū as jutsu and gendai budō as dō, the Maussian concept of bodily techniques could be of use.

Marcel Mauss uses the term bodily technique to encompass the effective and traditional act of doing something. If there is no tradition, no symbolic order or even no religious context, the concept of technique, at least in the Maussian sense, does not really exist (1998: 361-387). The Japanese term 
jutsu refers precisely to this ritualistic and maximum-efficiency-oriented technique. The main role of a jutsu student was to acquire skills necessary for him to survive on the battlefield, in an uncomfortable war environment, including spearmanship, swordmanship, swimming skills, combat tactics, strategic procedures and close-encounter drills. On the other hand, the transformation to $d \overline{0}$ could be seen as an appropriation of the old traditions, like in the case of jūjutsu to jūdō transformation. When commenting on jüjutsu, bare-arms techniques in classical Japanese martial arts, Jigoro Kano stated that he does not "necessarily believe all traditional training methods are valid", but that "with some reformation, bujutsu [old-school martial arts] training could very well become an effective means for nurturing the individual's intellect, physique and morality" (cf. Murata 2005: 145). Many Japanese martial arts succeeded in this transformation, either with a strong institutional support of Nippon Budokan, like sumō, with some help of a founding figure, like Jigoro Kano for jūdō and Morihei Ueshiba for aikidō, or because of a strong bujutsu-reformist personality, like Kenzo Awa for kyūdō, Funakoshi Gichin for karatedo and So Doshin for shorinji kempo.

It seems that there were at least three strategies at work in this transfer. For now I shall call them (a) demilitarization, (b) mystification and (c) cultural appropriation. The military context of koryū budō culture was definitely not appropriate for the contemporary martial arts culture, rooted in pacifist ideas. Traditional martial culture thus had to transform its own field-combat-oriented heritage towards more general, even modern ideas of self-development and physical conditioning, (kin)aesthetic and performative values, etc. Subsequently, this usually led to the "mystification of budō", whereby it was often interpreted as the most appropriate means for achieving spiritual stability, calmness of the mind, even Buddhist-like satori, etc. Many Western practitioners assisted in this processes of budō mystification or spiritualization. The German scholar Eugen Herrigel, a professor of philosophy, started learning kyūdō from Kenzo Awa and was enchanted by the esoteric mysticism of traditional Japanese archery. He came to Japan in 1924 as a professor at the Tohoku Imperial University and was fascinated by Eckhart's esoteric philosophy. This led him to take up an interest in Japanese philosophy. Suzuki states:

Following a process that differed from the modernization and international propagation of jūdō, a German philosopher with an interest in [Zen Buddhist] mysticism encountered a "spiritually enhanced" reinterpretation of kyūdō and conveyed this "spirit" of Eastern martial arts to Europe as the culmination of his studies in the art. (Suzuki 2005: 17)

Herrigel went on to write a book about his experience as a kyūdō practitioner. The book Zen in der Kunst des Bogenschiessens (1948; Zen in the Art 
of Archery) became a European bestseller and it was even translated into Japanese in 1959. The mysteries of the East were thus introduced to Europe through martial arts. ${ }^{6}$ Mystification processes like this one had both positive and negative effects on the understanding of budō culture in the Western eyes. Still, there is no doubt that this process helped in spreading Japanese martial arts throughout Europe during the 1960s to a great extent. The third concept, cultural appropriation of budo, is perhaps the most problematic one. On the surface, this process seems quite simple. Japanese martial arts, while being self-modernized/reformed by several founding figures, appropriated their legacy, in order to be more acceptable to non-Japanese practitioners. For example, Jigoro Kano introduced a grading system that had not existed in the classical martial arts styles. This kyū-dan system was later accepted by many other modern martial arts schools in Japan, although with different grading and progress requirements. As a consequence, modern budō schools started to be incorporated in the international physical activities and sport organizations (measurement of grade-progress was a Western requirement), even being studied through Western educational pedagogies.

Competitive, rivalry-oriented Western sport culture thus made an impact on the traditional values of Japan's most prominent cultural export. Although this definitely brought several positive (Western) values into the world of contemporary Japanese budō, especially while it was being interconnected with the original "Olympic ideals", some of its original values got lost on the way. ${ }^{7}$ On the other hand, the sociocultural heritage of pure non-competitive bodily techniques of budō is being revitalized today in many ways, e.g. by implementing traditional Kōdōkan forms in jūdō competition systems, by assuring corresponding educational principles in kyūdō, kendō, karatedō and aikidō. During the 1960s and the early 1970s some of the main Japanese cultural institutions, especially those connected with Nippon Budokan, were suddenly concerned with the cultural legacy of budō, because of the possibility that it would be lost. This was only partly because budō was sportified, westernized and internationalized. It is certain that there is a more complex logic of globalization and modernization behind this process, which I will not analyze at this point. ${ }^{8}$

${ }^{6}$ The Harvard psychologist Peter Payne's book Martial Arts: The Spiritual Dimension (1981) is an example of a guide to budō interpreted in this mystical way. Strong Zen components can nevertheless be traced in shorinji kempo, in different forms of aikidō, in kinomichi, kinokenkyukai, shinshintoitsu styles, etc.

${ }^{7}$ Both modern karate and jūdō participate in the contemporary sport arenas as competition-oriented disciplines, but, on the other hand, there are very few schools outside Japan teaching traditional Kōdōkan forms.

${ }^{8}$ Similar developmental strategies could be recognized in most other bodily disciplines, as well as in some of the modern (Olympic) sports, as some scholars already showed in the case of contemporary "running culture", again relying on Maussian anthropological legacy of the "embodiment and bodily techniques" (Christensen and Damkjaer 2012: 187-2012), or as shown by some researchers dealing with dif- 


\section{ANCIENT WAYS AND MODERN BUDŌ}

In the history of Japanese martial arts styles there is a sharp division between modern martial arts, for example the above-mentioned - jūdō, karatedō, aikidō, kendō, kyūdō, usually called gendai budō - and traditional martial arts heritage, referred to as koryū budō, koryū bujutsu or kobudō. Modern budō, such as shōrinji kempō, karate, jūdō, aikidō or kyūdō, have their roots in the classical systems codified from the end of the Heian period (794-1185) through the Tokugawa period (1600-1868) of Japanese military history, in the martial arts technical heritage that is often divided into different styles, schools or traditions (ryūha). ${ }^{9}$ One of the first categories of combat traditions developed in the early Heian era was mounted archery (kyūba jutsu) and one of the oldest sword routines was the one belonging to the Kashima tradition (Yokose 2009: 87-89). It is very important to mention that all the traditions of koryū budō were technically composite or integrative traditions (sōgō jutsu). Due to the realities of the war the feudal soldier had to be trained in various combat skills, in armed or unarmed techniques, horsemanship, swimming strategies, military tactics, etc. For example, one of the oldest traditional koryū budō schools, Shintō-ryū, employed techniques of armed and unarmed combat, knife throwing, spearmanship, swordsmanship and even pseudo-engineering. Broadly taken, koryū budō could be categorized into the following (heterogeneous) groups: bujutsu or horsemanship, kyüjutsu or archery, kenjutsu or swordsmanship, sōjutsu or spearmanship, naginatajutsu or glaive techniques, bojjutsu or long staff techniques, kamajutsu or sickle techniques, jujjutsu or unarmed and small-armed close combat techniques, suijutsu or tactical swimming and hojjutsu or musketry techniques. The technical repertoire of jūdō or aikidō, to offer just two examples, is more influenced by the armed koryū school and traditions (bugei) than by the unarmed ones. From the performative standpoint, as I will try to show later on, this is very important, not only because it sheds a different light on the relatively unknown history of the Japanese budō but also because it tells us a lot about the structure of movements in these modern martial arts systems. ${ }^{10}$

ferent movement pedagogies, who relied on certain recent contributions Asian-European cross-cultural philosophy and the anthropology of the body (Yuasa 1987, 1993, 2008) and embodiment (Shusterman 2008, 2012). Richard Shusterman examines interesting concepts of muscle-memory or body-consciousness in performative disciplines, using sources from Eastern philosophical traditions (Japanese, Indian and Chinese) alongside Western phenomenological (Merleau-Ponty) and post-modernist theory (Foucault). Nevertheless, these issues exceed the limits of this paper. The problem of globalization of budō can be easily exemplified by sumō, prevalent today in Mongolia, the United States etc.

${ }^{9}$ The term is often used synonymously with ryū and ryūgi. It was probably coined during the Edo period, due to political conflicts over the succession of the style or a lineage, in a parental sense of the word.

${ }^{10}$ There are, of course, even more elaborated systematizations of koryū groups, according to combat skills, types of weapons used or both (Hall 2012: 11-12). The Japanese inherited the list of martial arts 
The history of classical Japanese martial arts is full of reconstructive procedures. Not much written evidence, apart from technical or kinaesthetic evidence, has survived. It is evident that during the Tokugawa period (1600-1868) the number of styles suddenly increased, at one point reaching close to one hundred known ryūha. By the end of the 1800s, the mystical aura surrounding budo had already been created, mainly interconnected with the neo-Confucian philosophy from China, different traditions of esoteric Buddhism and Shinto religious rituals, etc. This aura is connected with Oriental martial arts even today, although it is useless to analyze them only in this manner as "Zen-arts", as some do (Cox 2003). The increase of ryūha can be perceived pragmatically: Japanese military history demanded different patterns of physical education, especially in the domain of field-combat systems. This is why at the end of the 1600s Japanese historians mention fifty two styles of archery, seven hundred schools of swordmanship, more than one hundred styles of spearmanship and around two hundred schools of close unarmed and armed combat. During the Meiji period (1868-1912), before World War I escalated, the samurai class system was dismantled. After the Meiji Restoration in 1868, some of the traditional martial arts styles nearly disappeared. There were some efforts to preserve koryū budō as an important aspect of Japan's cultural heritage. Commercial martial arts shows and demonstrations (gekken kōgyō), for example, were often held to promote the historical values of the bushidō code and the koryū budō style legacy. ${ }^{11}$ Furthermore, in 1895 the Great Japan Association of Martial Virtue (Dai Nippon Butokukai) was established in order to preserve the ancient martial ways. Butokukai was founded in Kyoto by a small group of enthusiasts willing to conserve classical martial arts traditions, those which had not disappeared after the Meiji Restoration. In 1899 the group built the Hall of Martial Virtue (Butokuden) next to the Heian shrine in Kyoto. The main mission of the group was, unfortunately, to prepare young generations of the Japanese for war, especially by introducing jūdō and kendō into obligatory education by the end of 1911. The Japanese, their patriotic feelings and the State were thus brought into a lasting relationship and dynamic interaction with one another, by using nothing more than the metaphor of budo - standing for a unique national body (Gainty 2013).

from China, but the list often varies depending on the era and the location where it was compiled. It is usually called bugei jühappan or the list of eighteen martial arts.

11 The terms gekken and gekiken were used during the Meiji period for simulated combats with bamboo swords, similar to modern kendō matches with bamboo (shinai) swords. In an ethno-kinesiological sense, furthermore, many of the original techniques or koryū movement structures had to be redefined, reorganized and modified for this modern competition-like (non-military) performance. This implies changing of the stance, positioning, arms, legs and trunk tensions, the elimination of dangerous techniques, etc. 
However, this is an extreme example of the misemployment of the national budō heritage. As I mentioned earlier, Jigoro Kano also played a great role in preserving koryū budō schools, mainly because he claimed that most jūdō techniques were inherited from different traditions: Kitōryū, Daitōryū and Tenjin Shin'yoryū. Furthermore, some experts in different styles of koryū even collaborated to create a unique budō-education curriculum, for example the one for kendō examinations. In 1912, a unique set of forms (kata) for kendō was created, in order to represent some of the fundamental principles of different traditional swordmanship schools. It became an example of the inner appropriation of koryū to gendai budō. As of 2009, the All Japanese Budō Association (Nippon Budōkan) acknowledges seventy eight koryū budō styles with clear lineages and traceable history that have been affiliated to the Japanese Classical Budō Association (Nippon Kobudō Kyokai). Surprisingly, as the central organization for all Japanese martial arts, both modern and traditional, Nippon Budōkan was founded and then reopened on the occasion of a westernized sporting event: the Tokyo Olympics of 1964. ${ }^{12}$ Modern educational theories greatly influenced the main mission and all of the activities of the Budōkan. Today, researchers in the field of interconnections between modern and traditional martial arts systems play an important role in most Japanese universities and faculties specializing in the field of physical education, anthropology of structured movements and cultural history. Many dozens of koryū bujutsu styles that are still alive, transmitting their knowledge to a dwindling audience, are thus, of course, considered to be Japanese national heritage precisely because of the efforts by the above-mentioned institutions. ${ }^{13}$

${ }^{12}$ After the Tokyo Olympics many Japanese instructors (Nobuyoshi Tamura, Masamichi Noro, Hiroshi Tada, Taiji Kase, Yoshinao Nanbu, Yoshimitsu Yamada, etc.) departed for Europe, the United States and Australia to teach budō.

${ }^{13}$ Because of the role and the importance of koryū bujutsu for the development of all modern martial arts, it is absolutely necessary to present at least some of the classical schools - not all seventy eight of them of course - that are listed on the Nippon Kobudō Kyokai list. I will do so using the most reliable secondary references available (Skoss 1997, 1999; Mol 2001; Yokose 2009; Hall 2012). Asayama Ichiden-ryū Heiho is a complex or integrative koryū school, probably founded in the Tensho (1573-1593) or Keicho (1596-1615) period in the Kanagawa prefecture. It was founded by Asayama Ichidensai Shigetatsu as a military form of landed farmer-warriors. It includes sōgō bujutsu weaponless and armed techniques. Hyoho Niten Ichi-ryū Kenjutsu is a swordmanship school founded by the legendary Miyamoto Musashi in the first half of seventeenth century in the Oita prefecture. In a technical sense, it is a very economical school with no exaggerated movements, famous for its two-sword techniques. Kashima Shinden Jikishinkage-ryū Kenjutsu is also a school famous for its swordmanship, which was founded in the late fifteenth or perhaps even the early sixteenth century by Matsumōto Bizen-no-Kami Naokatsu in the Chiba prefecture. It is often associated with Kashima shrine cults, and was initially called Kashima Shinden-ryū. Another sword-oriented school is Kurama-ryū, founded in the early Tensho period by Ono Shokan in the Tokyo prefecture. This school was very active in the above-mentioned Meiji nationalist movement, offering a variety of techniques to the police and military services. Maniwa Nen-ryū was founded in 1368 by Soma Shiro Yoshimoto, who later became known as Nen Ami Jion, in the village of Maniwa in the Gunma prefecture. This style is one of the oldest surviving traditions of swordmanship in Japan. Morishige-ryū Hojutsu is a musket-oriented school, founded in 1803 by Morishige Yukie Tsuyoshi in the Kanagawa 
Most koryū schools strongly influenced modern budō. Here are three examples: Jigoro Kano, the founder of Kōdōkan jūdō, included many techniques of Tenjin Shin'yo-ryū in his curriculum, especially in Itsutsu no kata, known to most of jūdōka; the Daito-ryū Aikijutsu school, established by Takeda Sokaku during the Meiji period, ${ }^{14}$ had an enormous influence on the formation of Morihei Ueshiba's aiki(bu)dō; Kito-ryū lineage, founded around 1637 by Ibaraki Sensai, was also incorporated into modern jūdō by Jigoro Kano, which is visible in the Koshiki no kata. These traditions are being studied even today, not only in a practical manner, but also as the subject of ethnographic interest. On many occasions, during different hōnō embu, votive martial arts demonstrations and festivals, koryū bujutsu culture is presented to the public in all its technical and aesthetical diversity. The most important exhibitions are performed in a ritual context of Shinto shrines, including Katori, Kashima, Meiji and Ise Jingu and Yasukuni Jinja, to name just a few (Hall 2012: 448-449, sub voce Shinto). ${ }^{15}$

prefecture. These firearms used in Morishige-ryū, based on Portuguese harquebus musketry, played an important, even a revolutionary role in the Japanese modern military history. Owari Kan-ryū Sojutsu is also an integrative koryū school, using many weapons like most schools, founded in 1671 by Tsuda Gonnojo Taira Nobuyuki in the Aichi prefecture. A very similar koryū is Shingyoto-ryū Kenjutsu, a late seventeenth century style, founded by Iba Josuiken Hideaki in the Mie prefecture (around 1682). One of the oldest schools of swordcutting (battōjutsu) and sworddrawing (iaijutsu) is considered to be Shinmuso Hayashizaki-ryū Iaijutsu, established by Hayashizaki Jinsuke Shigenobu in the late sixteenth century in the Tokyo prefecture. Two of the oldest and thus less known integrative schools of koryü are often considered to be Tendo-ryū Naginatajutsu, established in 1582 around Kyoto by Saito Hangan Denkibo Katsuhide, and Yagyu Shingan-ryū Taijutsu, probably dating to the early 1600s, founded by Araki Mataemon in the Kanagawa prefecture. During the Muromachi period of Japanese history (1658), Yagyu Shinkage-ryū Hyoho was established in the Aichi prefecture, using several even older traditions as its founding lineage. One of the most comprehensive schools in koryū budō history is definitely Yoshin-ryū, known for its jūjutsu techniques. It was created in the Hiroshima prefecture by Akiyama Shirobei Yoshitoki who learned both combat and healing techniques in China around the 1600s. Two koryū traditions established during the Muromachi era, very complex in their nature, are Toda-ha Buko-ryū, founded by Toda Seigen around 1560, and Tenshin Shoden Katori Shinto-ryū, founded by Iizasa Choisai Ienao around 1447. The latter is even considered to be one of the oldest martial arts schools in Japan today, with a well-preserved and traceable educational curriculum, closely connected to services around the Chiba feudal family. Very old and complex koryū schools from the Okayama region are Takenouchi-ryū, founded around 1532 by Takenouchi Chunagon Daijo Hisamori, and Shojitsu Kenri Kataichi-ryū, founded by Imaeda Sachu Ryodai around 1680. Documents about Tatsumi-ryū from the Chiba prefecture and Shinto Muso-ryū can be rarely found, although the latter, established around 1640 by Muso Gonnosuke Katsuyoshi, was spread all over Japan. One of the most influential schools of the so-called close-combat was definitely Sekiguchi Shinshin-ryū from the Wakayama prefecture. It was founded by Sekiguchi Yarokuemon Ujimune as a series of grappling patterns which have influenced many modern Japanese martial arts.

${ }^{14}$ Takeda Sokaku Minamoto no Masayoshi (1859-1943) was one of the most influential figures in Japanese martial arts history. The founder of Daitō-ryū jūjutsu and aikijüjutsu, Takeda, was very skilled in several koryū budō traditions. His most famous students were Morihei Ueshiba (1883-1969), who later established aikidō, and Hisa Takuma (1895-1980), the founder of a less influential school of Nipponden aikijūjutsu.

${ }^{15}$ Some scholars, like Diane and Meik Skoss and David A. Hall, conducted many studies on the problems of integrating these field ethnographic data into the broader historical context of the koryū culture. They created a large documented database, also available in digital format, and always categorized by the exact style and lineage. Furthermore, they also created encyclopedic explications for those who are 


\section{THE CONCEPTS OF BUDŌ: FROM PEDAGOGY TO ANTHROPOLOGY OF PERFORMANCE AND BACK}

Technical repertoires of the modern martial arts, jūdō, kendō and aikidō, are extremely wide-ranging and interesting enough to be analyzed from various standpoints. Contemporary scholars of modern martial arts often overlook the fact that there is a vast field of kinaesthetic knowledge, technical, tactical and strategic skills, hidden somewhere beneath the surface of these modernized systems of techniques (waza). Being deeply inscribed into the modern martial arts techniques, but also, for many different reasons, into the modern Japanese perception of their own tradition and/or their own cultural heritage, this knowledge begs systematic sociocultural study. My analysis would fit into what may be termed, in the broader sense of the word, ethno-kinesiological research, first and foremost due to an overall attempt to encompass the pre-structured, pre-ritualized and formalized movements based on the background of many complex Japanese martial arts/budō systems. Many disciplines of humanities and social sciences today try to interpret koryū budō through a number of, in some instances, different approaches. But, if one would wish to interpret koryū budō as an "old tradition" or an "old school" of martial arts, it would be important to define the distinction between the "old school" and modern martial arts. This can be done, for example, by using the pragmatic distinction first employed by Donn F. Draeger in his book on classical budō. He claims that for the more modern arts of budō the ranking of priorities would have to line up from morals to discipline and from discipline to the purity of the aesthetic form. For the older ones, on the other hand, the hierarchy would be from combat efficiency towards discipline and/or morals (Draeger 1973: 36). Although such a distinction is quite Maussian in its nature, it nevertheless proves to be far from sufficient. Traditional koryū budō schools have the same, or almost the same, waza list and technical repertoire like their modern or contemporary successors. However, much of the interpretations depend on the concept we refer to when using the notion of modern martial arts. Jūdō, karate, or even kendō and sumō, although in a transitional phase, were often perceived as sui generis combat-competitive regimes. Today they are defined by their polystructural and acyclic composition, while their conventional and aesthetic surplus is often disregarded: one

not familiar with the socio-historical complexity of kobudō. One of the most important ethnographic resources of koryū budō embu is Steven Fletcher Radzikowski's non-profit digital collection, available and open to everybody interested in traditional Japanese martial arts, even through media like the ubiquitous YouTube. These demonstrations are held annually, and I even managed to participate in some of them, both as a participant-practitioner and an observer, during my visits in Japan, mostly from 2009 to 2013. The interconnections between Shintoism, (Zen) Buddhism or other religious movements and budō culture (e. g. the usage of kotodama, mokuso and misogi in aikidō practice) are very important, but unfortunately they exceed the limits of this paper. 
of the main technical aspects of karate, jūdō and kendō is actually rigorous technical competence in form (kata) performance. This part is, unfortunately, often neglected while defining the field of technical competence or movement structures of the above-mentioned modern martial arts. This is why, in my opinion, comparing traditional martial arts or koryū budō systems with the modern ones (gendai budō) could result in discovering some of the movement structures that lie beneath the modern budō's technical surface. This idea can thus be researched from various points of view and by employing different disciplinary positions, whereas I opted for an approach that will enable me to trace these movement (or technical) structures within the ritualization process visible in koryū budō.

These ritualized and formalized or pre-existent structures of movements I will refer to can be defined in the following ways: (1) as movement structures that can be found in military and physical education practices of the koryū budō systems which were employed mainly on the battlefield as pragmatic or unconventional physical practices; (2) as movement structures that are deeply embedded in the Japanese society, as norms, conventions, customs; as "body rituals" in Maussian terms, which can be found in some other physical activities, such as traditional dance rituals, the tea ceremony ( $\operatorname{sadō}$, chadō), the kabuki performance and in Nō-theatre; (3) as movement structures that are conventional, standardized, kinaesthetic or formative, including pre-arranged sets of techniques and special skills to be acquired/ transmitted by a hereditary line (iemoto). All the above-mentioned specificities, as I explained in the introduction, can be found in UNESCO's Articles 1-3 regarding intangible cultural heritage. However, they can be grasped in an ethno-kinesiological sense if budō is pre-defined as a concept constructed from five distinctive but interrelated characteristics: (a) combative (bujutsu-sei), because it evolved from attacking and killing techniques into a way of self-cultivation (shugyō) or introspection; (b) religious (shukyō-sei), because at one point it became associated with the folk religion and rituals, especially with Shinto; (c) aesthetic (geidō-sei), because it was closely connected with arts and humanistic education (bun-bu-ryōdō); (d) educational (kyoiku-sei), because during the peaceful Tokugawa period principles of the warrior-gentlemen (bushidō-shidō) were codified; (e) competitive (kyogisei), because some disciplines were transformed into modern competitionoriented sports. Ritualistic components, nevertheless, emanate throughout these elements and they have already become international trademarks of budō tradition.

There are dozens of ritual-like movements that are traceable in budō culture, including the following ones: a specific way or style of walking (namba aruki); pattern structures learning procedures usually called kata; corporal differences between the inside and the outside of the body or uchi/ura and 
soto/omote sides; the position of awareness usually called kamaeru; the fully seated position of the body for combat purposes (suwari); the incorporation of armed techniques in pre-arranged sequences of unarmed combat; military correspondence between execution (waza), distancing ( $m a$ ) and tactics (heiho), etc. The ritual-oriented nature of Japanese martial arts is evident at first sight. When you enter a dōjō, whether you are in Japan or not, you will see the practitioners bowing to each other, showing respect to their teachers, to the other practitioners, to the symbolic order of the school, etc. In budo everything starts and ends with rei, designating respect. The ritual of "expressing respect" can be divided into two main categories, one where the respect is a social mode of addressing or communicating and the other where the respect is also an expression of one's wish to remain in peace:

The kinds of rei prevalent in the budo of the modern period can be categorized in the following manner: [the first one] based upon Confucian principles which make a clear distinction between the self and others, and also demonstrate the will to maintain harmonic relations [like some kind of] a socially established pattern of contact; [the second one could be] seen in Buddhist theories of disciplining the mind through tempering the body [and the third one designates] a Shintoistic ritual used for purification when crossing from the mundane into sacred realm. Given such categories, the first shido-type rei was developed in the bushi [ex-warrior] society of the Tokugawa period, and corresponds to the role of rei in modern budo to control the emotion, and stop it degenerating into an act of unbridled violence by maintaining order, and emphasizing the importance of showing respect to one's opponent. This, of course, is a valid interpretation of the role of rei. However, the second category of an internal shugyō-type rei, where the adept [inside or inner student] performs actions expressing rei or adherence to propriety as they throw themselves into hard physical training, pushing their own limitations as they seek a deeper understanding of their very existence. This is a non-superficial type of rei which is of the utmost importance in budō training. Furthermore, it is this category [of rei] which needs to be explored, developed to suit the times, and stressed if budō education is to continue to be of use to future generations. (Irie 2005: 161)

The opposite process of deritualization of budō legacy is also evident enough. It has already started after the Meiji era, with many modifications, including those of the kinaesthetic, technical and organizational nature. The movement structures mentioned before thus function as ethno-kinesiological patterns, ritual forms, transmitted from koryū to gendai budō. A good example of this are the namba aruki walking style and kata pattern of transmission, mainly because of the fact they were well preserved, both in koryū budō and many modern Japanese martial arts. Technical material for a variety of ethnokinesiological changes could thus be found in many ancient texts about 
warfare strategy and combat tactics, in kinetographical sources available in many hereditary scrolls (densho), explaining the specificities of a certain school and lineage, etc. But only kata form patterns tend to keep the system of techniques almost preserved, from koryu to modern budo ${ }^{16}{ }^{16}$ Nevertheless, not many facets of the Japanese martial arts culture have been as consistently misunderstood as kata. It was variously described: as a kind of rituallike and ritualized combat, as an exercise in the kinaesthetic manner, as a moving meditation, often as a training method wherein students rehearse or simulate combinations of techniques, counter-techniques, or sequences of such combinations - but in exactly the same manner and style as they were taught (Friday 1999). On the other hand, some scholars suggested that the most suitable translation for the Japanese term kata, instead of the everpresent "form", should be "pattern practice", because in a broader sense, kata is a pattern structure of the Japanese society and culture in general, used in calligraphy training, in learning languages, in theatre practices etc. All of Japanese performance-like practices on UNESCO's list of intangible cultural heritage, even some of the craftsmanship, can be defined as pattern-like (kata) forms.

There are several functions of kata that are preserved in modern budō: the metacognitive function, because kata essentially always trains bodily cognition; the pedagogical function, because this is the way to transmit knowledge of a certain pattern in a certain martial arts school; and the archival function, because the exact learning and relearning of the formative and ritualized patterns of kata preserves all of the structures of movements in the existing style, employing the kinesthetic experience as a dominant one. Modern martial arts have preserved kata patterns in two ways. The first one is the original Japanese way, and its sources are in koryū budō, where kata actually

${ }^{16}$ Koryū budō schools of the Edo era have kept a distinct way of walking as their movement specificity. This is usually called namba aruki. It was primarily just a walking style used by the messenger during the Edo period of the Japanese history (1603-1868), whose job was to quickly distribute messages between Edo and the other Japanese provinces. He would usually walk long distances, such as from Edo to Kyoto, being approximately five hundred kilometers, in around six days. This style of walking thus employs hips in a totally different way from today's translatory hip movements, or the so-called western style walking. Why? Because namba aruki uses the principle of moving the same hand and the same foot forward in the same time. There are several reasons for this pattern of movement: it was supposed to decrease the swinging of the samurai sword, minimizing tiring as well. The remnants of this biomechanics of walking can be seen today in many modern martial arts, as it was obligatory to learn it in koryū budō systems. For example, in modern aikidō most of the entering based principles in throwing techniques (irimi nage) are based on the procedures of namba aruki; sliding techniques (tsuri ashi) in kendō and karate have the same background; sliding and approaching movements of the attacker and disbalancing (kuzushi) procedures of the defender in most of the jūdō kata employ the same principle. Today namba aruki is also used in a different manner, as an alternative training method in all other sports activities. There are a number of semi-professional or professional athletes in Japan who trained this method and set some records in different athletic disciplines. Shingo Suetsugu is the most famous example, because he set the all-Asian record in two hundred metres using this training method. One of the most famous Japanese martial arts scholars, Yoshinori Kono, still performs ethno-kinesiological research on the method (Kono 1986, 1987). 
means pre-arranged sparring between two partners, or where one of them takes the initiative of the attacker and the other of the defender. These kinds of pattern-like practices exist in kendō and jūdō, to name just two of them. The other way of understanding kata is of Chinese origin, as it was imposed in Okinawan karate, where the emphasis is placed on solo-form-performance. However we interpret it, kata is always a compendium of techniques (waza), and it has its roots in neo-Confucian philosophy. Learning through pattern practice derives from the Confucian obsession with ritual and ritualized movements, where ritual is a stylized action and formalist reduplication of the pre-learned bodily knowledge (Friday 1999: 157). In modern budō, kata practice is usually opposed to some sort of fully-free or semi-free sparring, usually called, in Japanese martial arts terminology, kumite, randori and jigeiko. In a way, free combat movements (randori) naturally stem from the kata practice because learning kata allows freedom of movements in real combat. Even in the Japanese language, kata in budō systems is written using a different ideogram or kanji when it is used to designate pattern practice of the tea ceremony, flower arrangement, theatre practice etc., because the budō ideogram represents the changeable and modifiable nature of budō's kata. The process of deritualization of modern (sports-oriented) budō is closely connected with the loss of the importance of pattern practice and pattern learning, for example in contemporary jūdō, where paired kata is rarely a part of training.

The rituality of koryū budō is not preserved only in the modern Japanese martial arts culture. It has become an integral part of various movement traditions and, especially, integration-oriented movement pedagogies. Thus, when the Italian theatre anthropologist Eugenio Barba offered examples that would support his theory on pre-expressional and pre-existent codes of movement, which are transcultural, i.e. mutual to all cultures, the budō culture featured high on his list, among other Asian traditions, especially Indian, Chinese and Japanese. Nevertheless, rather than interpreting the specific techniques of the specific traditions of Japanese, Indian, Chinese or Balinese performance rituals, he relied on the universal principles of positioning (called kamaeru in budō terms), decisiveness (designated as kimeru in budō) or walking patterns, namba aruki, thus using the budō terminology of "tension repositioning" or "a specific pattern of walking". ${ }^{17}$ In their

\footnotetext{
${ }^{17}$ In the following example Barba designates the difference between daily and extra-daily biomechanics of the body technique and, in general, body movements: "The purpose of the body's daily technique is communication. The techniques of virtuosity aim for amazement and the transformation of the body. The purpose of extra-daily techniques, on the other hand, is information: they literally put the body inform. Herein lies the essential difference which separates extra-daily techniques from those which merely transform the body" (1999: 10). He offers example of hip-usage and walking: "In Japanese, koshi is not an abstract concept, but a very precise part of body, the hips [...]. When we walk using daily body techniques, the hips follow the legs. In the Kabuki and Noh actors' extra-daily techniques, the hips, on the contrary,
} 
Dictionary of Theatre Anthropology: The Secret Art of the Performer (1991) Eugenio Barba and Nicola Savarese offer many additional examples from the Japanese performance and martial arts heritage, comparing their nuclear principles within the Western practice.

Indeed, a significant portion of Japanese intangible cultural heritage assets listed on the UNESCO list are deeply martial-like and koryü-like. For example, Nachi no Dengaku is a Japanese folk performing art connected to Kumano Sanzan, a sacred pilgrim's site in Nachisanku. Its dance-like components, in addition to containing musical patterns, abound with basic pattern principles from koryū traditions. The same is true of the re-enactment of samurai myths in Sada Shin Nō-performances. Kumiodori is a Japanese, Okinawan folk performing art, with many elements from mainland theatre performance practices and Chinese tradition of dancing. It had a great influence on the Ryūkyū (Okinawa) Islands classical kobudō traditions and even on early karatedō development. Most of these performances have lost their ritual and religious functions but nevertheless kept their, in Eugenio Barba's terms, extra-daily movement or kinaesthetic structures. This means that they are more dependent on a broader sociology, philosophy or even anthropology of the body than on their religious (usually Shinto) background as such. ${ }^{18}$ Thus they would fit into what Hylland Eriksen once stated: "One of

remain fixed. To block the hips while walking, it is necessary to bend the knees slightly and, engaging the vertebral column, to use the trunk as a single unit, which then presses downwards. In this way, two different tensions are created in the upper and lower parts of the body. These tensions oblige the body to find a new point of balance" (1999: 10-11). This body that searches for a new tension, producing a new dynamics, that comes naturally soon afterwards, is called a decisive or decided body. Interesting research in this direction can be seen in Phillip Zarrilli's work (1993; 2000).

${ }^{18}$ Many ritualized aspects of koryū budō, either way around, have something to do with what Westerners would recognize as the specific perception of the body, since Descartes's sharp distinctions between mindful rationality and bodily utilitarian, organical and biologically predetermined nature never existed in Asian cultures. The most famous in the plentitude of philosophical treatises where body (tai) and mind (shin) interdependences and interconnections are emphasized was written by the medieval philosopher Dogen Kigen (Shobogenzo, Shinji Shobogenzo, c. 1230s). His contemporary interpreters Ichikawa Hiroshi and Yuasa Yasuo rely on Maurice Merleau-Ponty's phenomenological studies, while using different Japanese body-mind philosophical traditions in order to appropriate them. Ichikawa does not distinguish the object-body and the subject-body because what is experienced or lived can neither be explained using the first logic, or the second one. This implies that both the object-body and the subject-body are synthesized in the concrete or pragmatic functioning of one's lived body. Or, in the view of the subject-body, the object-body is thus subjectivized because it enables us to incorporate it within the subject-body (my own hand that I am looking at is nevertheless my own, although it is an object in my perception). In Yuasa's theory of the body, what is particularly interesting is the point where he transforms Ichikawa's "ambiguous oneness" through personal self-cultivation (shugyō) into the "oneness of the body-mind". Yuasa claims that there are three information circuits regulating perception: the external sensory-motoric circuit, the circuit of coenesthesis and the emotion-intrinsic circle. The athlete who has mastered a set of techniques to move the body in a specific way embodies an enhanced capacity of the second circuit which in turn increases the level of activity in the first circuit. This is the goal of Western sports because the idea of controlling the emotion-instinct circuit is not taken into account. The Eastern performance practices, martial arts above all, concentrate precisely on the emotion-instinct circle, using different methods of controlling emotions, conscious integration, 'unconscious quasi-body' methods such 
the most famous analyses of rituals does not even deal with a religious ritual but a Balinese cockfight [he is referring to Clifford Geertz's interpretations from 1973], while in the mid-1990s a team of Norwegian anthropologists carried out research on the 1994 Winter Olympics, which they saw as an enormous ritual celebrating and legitimating modernity" (2010: 227). All of these characteristics were typical of the transformation processes between koryū and gendai budō, as it was previously elaborated. So, when applied to the history of martial arts, rituality functions rather as a cybernetic multivariate system than a structural or functionalist-oriented one. One possible integrative approach for the concluding arguments about koryū budō can be found in Richard Schechner's performance theory. ${ }^{19}$

\section{CONCLUSION: PATTERN-LIKE PERFORMATIVITY}

Japanese martial heritage was often analyzed from two extreme points of view, one being a biomechanical analysis of the combat systems, which is only one small part of the comprehensive technical repertoire of modern budō, and the other being the entirely esoteric and mystical aspect (Mol 2001). The former pattern of analyzing martial arts is somehow reasonable because they have slowly been transformed to competition-oriented physical activities. But the latter one - a mystic or esoteric pattern of analyzing the Japanese budō heritage - is the more dangerous one, because it reduces the complexity of the relationships between traditional and modern budō to Zen-philosophy, Buddhist mysticism and other religious/contemplative practices that have become a part of budō curriculum very recently. The ob-

as the employment of ki-energy exercises, etc. (Nagatomo 1992; Yuasa 1987, 1993, 2008). One of the best known founding figures in the Japanese budō, the founder of aikidō Morihei Ueshiba, once wrote about the principles of adjusting mind and body in a practical sense of real combat. During 1938, in the period of raging Japanese militarism, he wrote that "the appearance of the 'enemy' should be thought of as an opportunity to test the sincerity of one's mental and physical training, to see if one is actually responding according to the divine will. When facing the realm of life and death in the form of the enemy's sword, one must be firmly settled in mind and body, and not at all intimidated; without providing your opponent the slightest opening, control his mind in a flash and move where you will - straight, diagonally, or in any other appropriate direction. Enter deeply, mentally as well as physically, transform your entire body into a true sword, and vanquish your foe. This is yamato-damashii, the principle behind the divine sword that manifests the soul of our nation" (Ueshiba 1996: 31). In this brief passage from Budō, the first practical manual about aikidō, lots of elements of the above-mentioned body attunement or mind-body unification can be seen, as well as the esoteric-mystic background of the modern aikidō development, the importance of weapon examples in weaponless martial cultures, etc.

${ }^{19}$ There are several authors and Japanese budō practitioners who employ perceptive-principles in their practice, in accordance with, for example, Yuasa's explanations. Interesting psycho-physiological studies were recently done by Ushiro (2008) and Yamato et al. (2013). Perceptive-reaction principles in martial arts, such as kendō, are usually referred to as abrupt-switching-quick-response behavior (Yamato et al. 2013: 1-9). 
jective of the paper was thus different, to show that modern Japanese martial arts inherited a lot of elements from the ancient styles, as well as that most of the movement structures used in modern budō actually descend from koryū budō heritage, either by direct lineage or by indirect influences, as in the example of aikidō and jūdō. Different modern martial arts preserved this koryū heritage in a different way, either by making an implicit technical distinction between kata and randori, as in jūdō, wherein kata systems function as a memory machine for keeping the koryū traditions alive. Or, like in aikidō, where different aspect of koryū budō movements are preserved in the technical domain, especially in entering techniques (irimi tenkan) or disbalancing techniques (kokyu nage) and seated techniques (suwari waza). In sumō, kyūdō and kendō reference to old-school martial arts is preserved in the ceremonial context of actual combat, explicit in the opening sumō rituals, in the appearance of techniques, arenas where the actual practice and the competition takes place, etc. The role of classical martial arts is formative. This is actually a role of every performance practice or extra-daily routine: it thus generates not only technical data, a repository of movements, but also an external (ritualized) context. Schechner believes that performance ought to be interpreted as the global context of doing something in an extra-daily surrounding. It encompasses plays, games, sports, theatre-like production and pure rituals, predefined by a special ordering of time, a special value for its objects, rules and ongoing places, the type of assertiveness, scriptedness, self-transcendence, etc. (Schechner 2005: 16). The author uses the following scheme to define the most natural context for performativity as a concept (four of Schechner's categories can be easily applied to koryū budō preritualized performativity): his first category is called drama, in the broadest sense of the word. It includes technical/pragmatic "heated up" circles of performativity, all that can be taken from place to place or time to time independent of the person who carries it. In Japanese koryū budō traditions, as well as in most of Japanese performance practices, this could signify waza or the most heated and thus transmittable aspect of the art. Indeed, if we look at the UNESCO's intangible cultural heritage production strategy, it is obvious that the technical aspects of dance-like and performance-like practices on the list are the most important ones. The second circle of Schechner's scheme is called the script and it includes everything that can be transmitted from place to place or, in a linear-temporal way, from time to time, as the "basic code of the events". Most of the aspects of the Japanese pattern or form thinking, in the sense of the real kata scheme, can be recognized in Schechner's following statements: firstly, the script is transmitted from person to person; secondly, the transmitter is not a mere messenger, because the transmitter of the script must know the script and be able to teach it to others; and thirdly, his teachings may be conscious or done through empa- 
thetic and emphatic means. The first characteristic can be included in the Japanese iemoto principle, the hereditary line of the encoded transmission, the second and the third one in the so-called isshin-denshin principle that lies in the basis of the koryū budō education system and reduces the rational transmission principle to an emphatic one. Schechner's third circle consists of theatrical formativity. In the context of koryū culture it could be referred to as kata, the hereditary principle of pattern-like, formalized, kinaesthetic motoric knowledge. For Schechner this circle is concrete and immediate, consisting merely of techniques, it is a manifestation of the scripted sequences or waza, in koryū budō terminology. The widest circle of the ritualization context is referred to as performance or performative activity, and this is the broadest, "most ill-defined disc", including the whole constellation of events that take place among the audience and performers from the time the first spectator enters the field of performance to the time the last spectator leaves (Schechner 2005: 71). In the koryū context this widest circle of practitioners' performativity is called embu - a presentation of the complete kinaesthetic and motoric knowledge in a precise way. Presentations are usually performed in a ritualized context of Shinto shrines, as it was mentioned earlier, usually overemphasizing its own rituality by mixing different religious traditions, Shintoist and Buddhist in origin. Each embu usually has an eruptive proxemic structure, with a heated centre where the actual performance takes place and the cooling rims where the audience, whether fixed or just passing by, is located. The sumō performance or the Ryokugikan sumō tournament managed to keep this eruptive structure with the clear distinction between Schechner's performative circles. In the sumō performance all the traces of koryū are evident: from the ritualized entrance, the opening ceremony, throwing salt as a purification ritual or hesitating to start the combat or a duel, etc. Schechner offers examples for this hierarchy of performative circles, thus demonstrating how the classical terms of drama, script, theatre and performance should be reinterpreted according to the multiplicity of forms included in the phenomena to perform, or to per-form, as the author often puts it. He believes that changing their semantics or modifying their nuclear meaning, in a way, puts them in a wider, even transcultural research context. The koryū budō classification, in a similar vein, seems comparable to Indian and Balinese terminology, elaborated by Schechner:

In Bali, theater and drama are fixed while the script floats in relation to them. The minute gestures of dance - the movement of fingers and hands, the way a torso is held and bent, the facial expression (or lack of it, the famous Balinese "away" look) - are fixed; so is the traditional story or story fragment: often a contest between good and bad demons or a fragment from Ramayana. But how long the theatrical gestures will be performed, how many repetitions 
of movement, what permutations or new combinations occur - these things are unknown before-hand, depending on the "power" of the trance and/or the creativity of the performers. In Indian classical music, the progression of every raga is known; this progression is the "drama" of the music. But how a specific performer or group will proceed from one phase or note of a raga to the next, and how the progressions will be organized (how many repetitions, sequences, speed, volume), are not known in advance, not even by the performers: the script evolves on the spot out of a relationship between the drama (raga) and the theater (particular skills of specific performers). (Schechner 2005: 87)

Koryū budō, consequently, should be perceived as a (kin)aesthetic phenomenon that once had a deep ritualistic meaning, with traces of this ritual-basedperformative-knowledge being still visible on many levels, from technical to contextual. Its public display or embu emphasizes this ritual-based component; naturally in the precise form of Shinto embu. Rituals in public, as some researchers put it, often do this - they emphasize their own rituality, either by emerging from the extra-daily practices (koryū budō is often something strange, peculiar, even esoteric for the contemporary Japanese), either by creating spontaneous shrine-like or temple-like pseudo-ceremonial and pseudo-religious contexts, as in sumō or kyūdō competitions (Santino 2007: 125-133). The modernization of koryu budō, in contrast, started in the nineteenth century and reached its peak after the Tokyo Olympics in 1964. A complementary process of sportification of both traditional and modern budō legacy reached its peak in the last decade of the twentieth century. Today koryū budō lineage and all its assets are endangered. Maybe the best way of preserving them is to institutionalize them: (a) either by placing them on UNESCO's list or (b) by showing their explicit impact on all modern Japanese martial culture disciplines. As I mentioned in the introductory part of this paper, all koryū styles should be perceived as Japan's intangible cultural heritage because they preserved all of the components of UNESCO's definition of intangible cultural heritage assets: (1) they are traditional, contemporary (modern) and living at the same time (expressed in the triade of koryu, gendai and embu); (2) they are inclusive and hereditary, which is evident in their ritual-performative structure (expressed in the kata-pattern-formhereditary and the iemoto principle); (3) they are all representative and community-based, always included in some wider Shinto ceremonies, etc.; (4) finally, the koryū budō legacy has a long tradition of institutionalization, first in the militarist, warship-oriented context of the Meiji period regime (which explains why most Japanese institutions had an internal inhibition in promoting koryū budō as national cultural heritage) and subsequently, after World War II, in the context of modern heritage-oriented research institutions like Nippon Budokan or the International Budō University (Kokusai 
Budō Daigaku), etc. In her book Theatre, Sacrifice, Ritual: Exploring Forms of Political Theatre (2005) Erika Fischer-Lichte approaches the modern Olympic Games as reinvented ritual-performance practices that have preserved their ritualist patterns as a rite of passage (2005: 69-86). The koryū budō legacy does not need this kind of re-invention because its history is traceable in many pattern-like movement strategies, in the pure phenomenology of "ritual kata", as well as a wide range of ethno-kinesiological resources, transmission scrolls, a small number of which were presented in this paper.

\section{REFERENCES AND SOURCES}

Barba, Eugenio and Nicola Savarese. 1999. A Dictionary of Theatre Anthropology. The Secret Art of the Performer. London, New York: Routledge.

Benedict, Ruth. 1954. The Chrysanthemum and the Sword. Patterns of Japanese Culture. Tokyo, Boston: Tuttle.

Bennett, Alexander. 2005. "Introduction". In Budō Perspectives, 1. Alexander Bennett, ed. Auckland: Kendō World Publications Ltd., 1-7.

Bennett, Alexander. 2005a. "Kendō or Kumdo. The Internationalization of Kendō and the Olympic Problem”. In Budō Perspectives, 1. Alexander Bennett, ed. Auckland: Kendō World Publications Ltd., 327-350.

Bennett, Alexander and Kano Sensei Biographic Editorial Committee. 2009. Jigoro Kano and the Kōdōkan. An Innovative Response to Modernisation. Tokyo: Kōdōkan Jūdō Institute.

Cho, Sungkyun, Udo Moening and Dohee Nam. 2012. "The Available Evidence Regarding T'aekkyon and its Portrayal as a 'Traditional Korean Martial Art'”. Acta Koreana 15: 2.

Christensen, Dirk Lund and Søren Damkjaer. 2012. "Traditional and Modern Running Culture among the Kalenjin of Kenya. A Historical and Anthropological Perspective". In The Anthropology of Sport and Human Movement. A Biocultural Perspective. Robert R. Sands and Linda R. Sands, eds. Lanham et al.: Lexington Books, 187-212.

Cox, Rupert A. 2003. The Zen Arts. An Anthropological Study of the Culture of Aesthetic Form in Japan. London, New York: Routledge Curzon.

Culiberg, Luka. 2007. Japonska med nacionalnim mitom in mitološko nacijo. [Japan in between a national myth and a mythological nation]. Ljubljana: Založba/*cf.

Draeger, Donn F. 1973. Classical Budō. The Martial Arts and Ways of Japan, 2. Diane Skoss, ed. New York, Tokyo: Weatherhill.

Fischer-Lichte, Erika. 2005. "Re-inventing Ritual. The Olympic Games". In E. Fischer-Lichte. Theatre, Sacrifice, Ritual. Exploring Forms of Political Theatre. London, New York: Routledge, 49-65.

Friday, Karl F. 1999. "Kabala in Motion. Kata and Pattern Practice in the Traditional Bugei". In Sword and Spirit. Classical Warrior Traditions of Japan, 2. Diane Skoss, ed. New Jersey: Koryū Books, 151-170.

Gainty, Denis. 2013. Martial Arts and the Body Politic in Meiji Japan. London, New York: Routledge.

Hall, David A. 2012. Encyclopedia of Japanese Martial Arts. Tokyo et al.: Kodansha International. 
Herrigel, Eugen. 1999. Zen in the Art of Archery. London: Vintage Books.

Hylland Eriksen, Thomas. 2010. Small Places, Large Issues. An Introduction to Social and Cultural Anthropology. New York: Pluto Press.

Irie, Kohei. 2005. "Budō as a Concept. An Analysis of Budō's Characteristics". In Budō Perspectives, 1. Alexander Bennett, ed. Auckland: Kendō World Publications Ltd., 155-170.

Kanno, Kakumyo. 2009. "From Bushido to Budō". In Budō. The Martial Ways of Japan. Alexander Bennett, ed. Tokyo: Nippon Budōkan, 66-70.

Kano, Jigoro. 2006. Mind over Muscle. Writings from the Founder of Judo. Tokyo et al.: Kodansha International.

Kono, Yoshinori. 1986. Omote no taiiku, ura no taiiku. [Insides and Outsides of the Physical Education]. Tokyo: Sojinsha.

Kono, Yoshinori. 1987. Bujutsu wo kataru. [On Martial Arts]. Tokyo: Sojinsha.

Mauss, Marcel. 1998. Sociologija i antropologija, 1-2. Beograd: XX vek.

Mol, Serge. 2001. Classical Fighting Arts of Japan. A Complete Guide to Koryū Jujutsu. Tokyo et al.: Kodansha International.

Motomura, Kiyoto. 2009. "The History of Budō in Schools". In Budō. The Martial Ways of Japan. Alexander Bennett, ed. Tokyo: Nippon Budōkan, 61-65.

Murata, Naoki. 2005. "From 'Jutsu' to 'Do'. The Birth of Kōdōkan Jūdō". In Budō Perspectives, 1. Alexander Bennett, ed. Auckland: Kendō World Publications Ltd., 141-154.

Nagatomo, Shigenori. 1992. Attunement through the Body. New York: SUNY Press.

Oboki, Teruo. 2009. "The Attraction of Budō". In Budō. The Martial Ways of Japan. Alexander Bennett, ed. Tokyo: Nippon Budōkan, 57-60.

Nitobe, Inazo. 2012. Bushidō. the Soul of Japan. Tokyo et al.: Kodansha International.

Payne, Peter. 1981. Martial Arts. The Spiritual Dimension. London: Thames and Hudson.

Santino, Jack. 2007. "Performative Commemoratives, the Personal, and the Public. Spontaneous Shrines, Emergent Ritual”. In The Performance Studies Reader. Henry Bial, ed. London, New York: Routledge, 32-46.

Schechner, Richard. 2005. Performance Theory. London, New York: Routledge.

Shusterman, Richard. 2008. Body Consciousness. A Philosophy of Mindfulness and Somaesthetics. New York: Cambridge University Press. [http://dx.doi.org/10.1017/ CB09780511802829]

Shusterman, Richard. 2012. Thinking through the Body. Essays in Somaesthetics. New York: Cambridge University Press. [http://dx.doi.org/10.1017/CB09781139094030]

Skoss, Diane. 1997. "Field Guide to the Classical Japanese Martial Arts". In Koryū Bujutsu. Classical Warrior Traditions of Japan. Diane Skoss, ed. New Jersey: Koryū Books, 59-87.

Skoss, Meik and Diane Skoss. 1999. "Field Guide to the Classical Japanese Martial Arts". In Sword and Spirit. Classical Warrior Traditions of Japan, 2. Diane Skoss, ed. New Jersey: Koryū Books, 59-86.

Sugie, Masatoshi. 2009. "Japanese Budō". In Budō. The Martial Ways of Japan. Alexander Bennett, ed. Tokyo: Nippon Budōkan, 27-34.

Suzuki, Sadami. 2005. "Twentieth Century Budō and Mystic Experience”. In Budō Perspectives, 1. Alexander Bennett, ed. Auckland: Kendō World Publications Ltd., 15-44.

Ueshiba, Morihei. 1996. Budō. Teachings of the Founder of Aikidō. Tokyo, et al.: Kodansha International. 
UNESCO. Identifying and Inventorying Intangible Cultural Heritage. UNESCO - ICH.

Ushiro, Kenji. 2008. Karate and Ki. the Origin of Ki - the Depth of Thought. Kanagawa: Aiki News.

Yamato, Yuji et al. 2013. "Joint Action Syntax in Japanese Martial Arts”. In PLoS ONE, 8-9.

Yokose, Tomoyuki. 2009. "What is Kobudō?” In Budō. The Martial Ways of Japan. Alexander Bennett, ed. Tokyo: Nippon Budōkan, 87-101.

Yuasa, Yasuo. 1987. The Body. Toward an Eastern Mind-Body Theory. New York: SUNY Press.

Yuasa, Yasuo. 1993. The Body, Self-Cultivation, and Ki-Energy. New York: SUNY Press.

Yuasa, Yasuo. 2008. Overcoming Modernity. Synchronicity and Image-Thinking. New York: SUNY Press.

Zarrilli, Phillip. 1993. Asian Martial Arts in Actor Training. Madison: Center for South Asian Area Studies.

Zarrilli, Phillip. 2000. When the Body Becomes All Eyes. Paradigms, Practices and Discourses of Power in Kalarippayattu, a South Indian Martial Art. New Delhi: Oxford University Press.

\title{
OBREDNI FORMALIZAM I NEMATERIJALNO TIJELO JAPANSKE KULTURE KORYŪ BUDŌ
}

\author{
SAŽETAK
}

U članku se analizira međusobni odnos japanske tradicijske kulture borilačkih vještina (koryū budō) i njezinog suvremenog pandana (gendai budō). Analiza se temelji na ideji upisivanja koryū budō na UNESCO-ovu listu nematerijalne kulturne baštine kao najstarijeg japanskog kulturnog dobra vezanog uz borilačke vještine. Prvotni prijedlozi u tom smislu javili su se u posljednjih desetak godina, a iznijele su ih neke japanske organizacije koje se bave borilačkim vještinama, npr. Nippon Budokan, posebice njegov Odjel za baštinu koryū. Formalizam koji je nalik obredu i koji se zasniva na unaprijed određenim formama a koji se javlja u suvremenom i tradicionalnom nasljeđu budō-a interpretira se kroz prizmu "japanske nacionalističke povijesti" nakon razdoblja Meiji restauracije. Stoga se naglašavaju strukture pokreta koje su i ranije postojale u obrednim praksama klasične budō kulture a koje su i dalje prisutne u suvremenim sustavima borilačkih vještina, što proizlazi iz njihove nasljedne izvedbenosti koja prethodi njihovoj formalizaciji.

Ključne riječi: koryū budō, gendai budō, obred, kata, japanske borilačke vještine 